\title{
Avaliação completa
}

\author{
A nova avaliação não é produto de um governo ou de um grupo, \\ mas de uma comunidade e de um povo.
}

\author{
Cristovam Buarque, ACS - Assessoria de Comunicação Social do Ministério da Educação
}

D urante muitos anos, a avaliação dos cursos universitários foi realizada por sua própria comunidade, sem a participação do setor público. A partir de 1996, o ministro Paulo Renato criou dois instrumentos de avaliação, chamados Avaliação das Condições de Ensino e Exame Nacional de Cursos (ENC), este apelidado de Provão. Foi um avanço, mas trazia limitações - só um deles, o Provão, tornou-se conhecido, e era o único critério usado para classificar os cursos; além disso, os dois instrumentos de avaliação eram tratados isoladamente. Algo como dois médicos diferentes, que não conversam entre si, medirem a temperatura e a pressão de um mesmo doente.

Não se fazia um check-up completo do doente, nem se apresentava uma receita para curá-lo. A nova geração da avaliação dos cursos superiores vai fazer o check-up e dar a receita médica. Para se fazer um check-up, é preciso continuar medindo temperatura e pressão, mas também analisar as demais condições do curso. E para se receitar o remédio adequado, deve-se definir o que precisa ser feito para corrigir os problemas identificados, firmando-se um pacto, entre instituição e governo, de que a receita será seguida. Para chegar a uma visão completa, a nova geração da avaliação vai se basear em quatro indicadores:

a) de ensino, avaliando o professor, por meio de informações que já constam da atual Avaliação das Condições de Ensino;

b) de aprendizagem, por meio da prova aplicada aos alunos, semelhante ao Exame Nacional de Cursos;

c) de capacidade institucional, considerando outros aspectos importantes necessários para indicar as condições de cada curso ou instituição;

d) da responsabilidade do curso para com as necessidades da sociedade, do Brasil e do mundo, verificando a transmissão de conhecimentos ligados aos problemas da atualidade, às demandas dos empregadores e às exigências da população.

Com base nesses quatro indicadores parciais será construído o Índice de Desenvolvimento do Ensino Superior, para cada curso e instituição, equivalente a um indicador completo do seu estado de saúde, muito além da simples temperatura e pressão. Com base no IDES, cursos e instituições serão classificados pelo Ministério da Educação. No entanto, os indicadores parciais serão divulgados com total transparência.

Assim, as pessoas que preferirem poderão continuar procedendo como antes, utilizando apenas as informações limitadas a um ou outro indicador. Da mesma forma, qualquer pessoa pode limitar o conhecimento de seu estado de saúde apenas à sua temperatura ou pressão - de forma simples, mas incompleta. Finalmente, o relatório dessa nova avaliação vai conter também um Protocolo de Compromissos, que será firmado por cada instituição, indicando ações para superarem suas dificuldades e limitações, ao longo dos anos seguintes - contratação e formação de professores, aquisição de livros, mudança no conteúdo dos cursos. A avaliação de cada curso levará em conta o progresso realizado entre uma e outra avaliação, permitindo o descredenciamento dos cursos que não forem bem avaliados nem cumprirem os compromissos assumidos no Protocolo. Nessa nova geração, a avaliação deixa de ser realizada apenas pelo INEP, o órgão de estudos e pesquisas do MEC. Ela incorporará a Secretaria de Educação Superior, encarregada de definir políticas do ensino superior. E será supervisionada por uma Comissão de Orientação que representará, ao mesmo tempo, a sociedade civil e membros da comunidade universitária. Essa comissão aprovará os critérios de pontuação propostos pelo MEC para combinar os diversos indicadores, e terá o poder de definir prazos de avaliação para cada curso, diferenciando cursos consagrados de outros que exijam cuidados permanentes. Considerando o escopo ampliado da avaliação, a meta de avaliar todos os cursos, e não apenas alguns, e o prazo necessário para que instituições e cursos cumpram com seu Protocolo de 
Compromisso, os cursos serão avaliados a cada três anos, a menos que más condições de qualidade recomendem uma avaliação anual. Em 2004, todos os cursos de educação, saúde e ciências biológicas serão avaliados.

Esta é uma nova etapa na sistemática de avaliação do ensino superior. Seu desenvolvimento não teria sido possível sem a existência do Provão e da Avaliação das Condições de Ensino, implantados pelo governo anterior, sem o trabalho realizado pela comissão de especialistas que elaborou a proposta do Sistema Nacional de Avaliação da Educação Superior (Sinaes), nem sem o intenso debate que o Sinaes provocou.
A nova avaliação não é produto de um governo ou de um grupo, mas de uma comunidade e de um povo que desejam ver todas as suas instituições avaliadas, com seriedade, sem fingimentos, de maneira completa e conseqüente. Esperamos que o exemplo que dá o ensino superior seja seguido pelas demais instituições públicas e privadas brasileiras. Que cada uma aceite ser avaliada junto à opinião pública e se comprometa, perante ela, a realizar as mudanças necessárias para melhorar sua qualidade e sua contribuição para com as necessidades do país e do mundo. $\square$

Artigo publicado no jornal O Globo em 02/12/2003

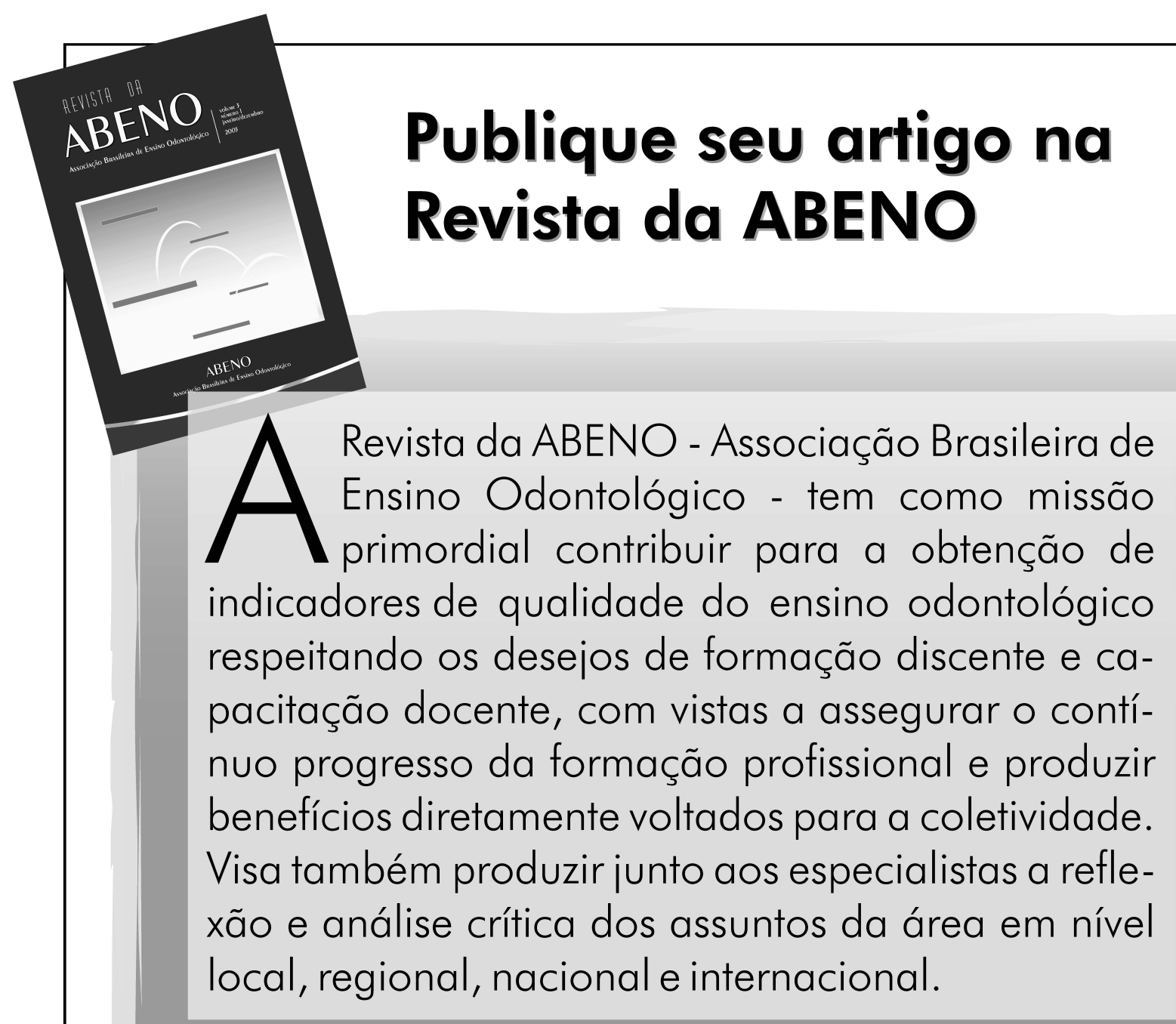

Envie seu artigo!

Veja as normas para a submissão de originais na página 94. 